\title{
UGDYMO DERME் AUKŠTOJOJE MOKYKLOJE
}

\author{
Doc. dr. Jūratė Guščinskienė \\ Generolo Jono Žemaičio Lietuvos karo akademija \\ Prof. dr. Jadvyga Čiburienė \\ Kauno technologijos universitetas
}

\begin{abstract}
Anotacija. Straipsnyje analizuojamos ugdymo problemos aukštojoje mokykloje. Pagrindinis demesys sutelktas $i$ ugdymo derinima šiuolaikineje aukštojoje mokykloje, $t$. y. $i$ ugdymo paradigma ir jos poveiki specialistu kompetenciju ugdymui žiniu visuomenès sqlygomis ir ju ịtaka pasauliniam inovaciju indeksui. Mokslinès literatūros ir statistiniu duomeny analizès pagrindu parodoma, jog Lietuvos žiniu visuomenę apibūdinantis pasaulinis inovaciju indeksas atsilieka nuo kitu Europos Sajungos (ES) šaliu nariu ir pasaulio valstybiu, nes mokslo tyrëju veiklos rezultatai ir žiniu darbuotoju skaičius bei ju produktyvumas Lietuvoje yra menki, nors žmogiškuju ištekliu pozicija yra stipri, tačiau ši rodikli lemia tik didelis bendras studentu aukštosiose mokyklose skaičius. Tai neigiamai veikia šalies konkurencinguma pasaulio šalių rinkose.
\end{abstract}

Pagrindiniai žodžiai: aukštoji mokykla, ugdymas, kompetencijos, inovacijos.

Ivadas. Išsivysčiusių pasaulio valstybių patirtis rodo, kad žiniomis grịstose ūkio veiklose, aukštujų ir vidutinio lygio technologijų pramonèje, plètojant mokslinius tyrimus ir vykdant eksperimentinę plètrą (MTEP), sukuriama didesné pridètinè vertė ir pasiekiama ne tik gamintojų, bet ir vartotojų didesnè ekonominè ir socialinè gerovè. Gebejjimai, žinios, kvalifikacija ir kompetencija tampa vis svarbesniu visuomenès gerovès užtikrinimo veiksniu ir reikšmingesne pažangaus, tvaraus ir integracinio ekonomikos vystymo strategijos prielaida.

Kita vertus, konkurencingumo didinimo svarbiausias veiksnys yra žmogiškasis kapitalas ir jo kuriama pridètinè vertè. Žmogiškojo kapitalo ugdymui, ypač jaunimo aukštojo mokslo lygmeniu, reikšminga ugdymo paradigma (mokymas, sąveika ir mokymasis) ir pedagoginio personalo kompetencijos. Studijos aukštojoje mokykloje suteikia ne tik išsilavinimą, bet ir suteikia problemų sprendimo ir mokslinių tyrimų valdymo gebejimų. Aukštojo mokslo ir studijų sistema siekia patenkinti visuomenès ir šalies ūkio siekius ruošiant įvairių sričių specialistus, gebančius nustatyti problemas ir rasti optimaliausius jų sprendimo būdus, todèl ekonomikoje vykstantys procesai yra žinių naudojimo pasekmè. 
Moksline problema - švietimo ir studijų aukštojoje mokykloje, mokslinių tyrimų ir inovacijų sąveika ir dermè.

Tyrimo objektas - ugdymas aukštojoje mokykloje.

Tyrimo tikslas - išanalizuoti ugdymo derinimą šiuolaikinèje aukštojoje mokykloje: ugdymo paradigmą ir jos poveikị specialistų kompetencijų ugdymui žinių visuomenès sąlygomis ir jų įtaką pasauliniam inovacijų indeksui.

\section{Tyrimo uz̆daviniai:}

- ištirti kompetencijų sampratą;

- aptarti aukštojo mokslo pagrindines charakteristikas;

- apibūdinti žinių trikampio vaidmenį ir svarbą aukštajame moksle.

Tyrimo metodai: mokslinès literatūros analizè, statistinių duomenų lyginimas, lentelinè ir grafinè analizé, interpretacija.

\section{Aukštais mokslas šiandieninėje visuomenèje}

Ivairiuose Europos Sajungos (ES) dokumentuose ypatingas dèmesys skiriamas mokymosi visą gyvenimą, švietimo ir mokymo sistemų tobulinimo, aukštojo mokslo problemoms, pvz., „Europa 2010“ (Industrial Relation in ..., 2010), „Europa 2020“ (Europe 2020, 2010), Europos aukštojo mokslo sistemų modernizavimo darbotvarkeje (2011), naujuose Europos kooperacijos prioritetuose (New Priorities for ..., 2015) ir kt. Dar 2000 m. kovo mèn. Europos Taryba Lisabonoje patvirtino, kad Europa neginčijamai ižžengè ị žinių amžių, kuriame mokymasis visą gyvenimą tampa būtinybe. Buvo pastebėta, jog darbuotojų žinios ir gebėjimai priklauso nuo išsilavinimo ir mokymosi visą gyvenimą. Vos vienas iš trijų 25-34 metų žmonių Europoje turi universitetinį išsilavinimą, palyginti su 40 proc. JAV ir 50 proc. Japonijoje. Išlaidos MTEP Europoje nesiekia 2 proc., o JAV jos yra 2,6 proc., Japonijoje - 3,4 proc. (Europe 2020, 2010). Pasaulio ekonomikoje išsivysčiusioms šalims vis daugiau investuojant ị aukštajị mokslą, ES šalims sunku atlaikyti pasaulinę konkurenciją žinių, inovacijų ir mokslo srityse. Tai lėmè, jog ES šalys iki $2020 \mathrm{~m}$. Europos bendradarbiavimo pagrindiniu tikslu numate paramą tobulinant valstybių narių švietimo ir mokymo sistemas, kuriomis siekiama užtikrinti (New Priorities for European Cooperation ..., 2015):

a) visų piliečių savirealizaciją, socialinių ir profesinių lūkesčių patenkinimą;

b) tvarų ekonomikos klestejjimą ir galimybių ịsidarbinti užtikrinimą, plètojant demokratines vertybes, socialinę sanglaudą, aktyvų pilietiškumą ir kultūrų dialogą.

ES atliktų mokslinių tyrimų pagrindu prognozuojamas specialistų, baigusių aukštaji mokslą, ir specialistų, dirbančių nekvalifikuotą darbą, $2020 \mathrm{~m}$. poreikis. Taigi, aukštajji išsilavinimą turinčių specialistų poreikis ES-28 didès: tokių specialistų darbo vietu paklausa augs nuo 29 proc. $2010 \mathrm{~m}$. iki 34 proc. 2020 m., o nekvalifikuotos darbo jègos paklausa tuo pačiu laikotarpiu sumažès nuo 23 iki 18 proc. (Rethinking Education: Investing in Skills ..., 2012, p. 3). Taigi, situacijos analizė rodo, kad ES šalyse ekonomikos pletrai reikia žmonių, turinčių ịvairiose 
srityse pritaikomų gebèjimų, informacinių technologijų kūrimo ir tobulinimo ịūdžių, kūrybingų ir lanksčių, gerai išmanančių savo profesiją. Vienas iš svarbiausių šiandieninių ES šalių plètros strategijoje (Europe 2020, 2010) iškeltų švietimo tikslų - pasiekti, kad iki $2020 \mathrm{~m}$. aukštajj arba lygiaverti išsilavinimą igytų 40 proc. jaunuolių (Europos aukštojo mokslo sistemų modernizavimo darbotvarkė..., 2011, p. 3). Šis išsikeltas tikslas rodo, kad žinios ir gebèjimai tampa viena pagrindinių galimybių, siekiant užtikrinti tiek individo, tiek visos visuomenès stabilumą ir saugumą, todèl planuojama, kad $2020 \mathrm{~m} .35$ proc. visų ES darbo vietų bus skirta labai kvalifikuotiems darbuotojams (Europos aukštojo mokslo sistemų modernizavimo darbotvarkè..., 2011, p. 2).

Aukštojo mokslo tyrinètojas Permanini (2009) pastebi, kad kai ekonomika plètojama aukštu lygmeniu, tai aukštasis išsilavinimas yra reikšmingesnis negu pradinis ar vidurinis išsilavinimas. Kiti tyrèjai (Mingat, Tan, 1996) teigia, kad pradinis ir vidurinis išsilavinimas yra svarbesnis žemo ir vidutinio pajamų lygio šalyse, o aukštasis išsilavinimas yra reikšmingesnis aukšto pajamų lygio šalyse. Praktika rodo, kad išsilavinimo augimas didina darbuotojų gebejimus, kūrybingumą ir jų novatoriškumą įvairiose ūkinèse veiklose, o tai lemia jų sukuriamos pridètinès vertès dydị ir jos augimą. Kaip rodo 1 pav. pateikti duomenys, $2013 \mathrm{~m}$. Lietuvoje bendrojo vidaus produkto dalis vienam gyventojui (BVPG) pagal palyginamosios galios standartus sudare 73 proc., palyginti su ES sukurtu BVPG lygiu. Šalių grupei, kurioje BVPG yra mažesnè negu 75 proc., be Lietuvos, dar priklauso aštuonios šalys: Graikija - 73 proc., Estija -73 proc., Lenkija -67 proc., Vengrija - 66 proc., Latvija - 64 proc., Kroatija - 61 proc., Rumunija - 55 proc. ir Turkija - 53 proc. Šalių grupei, kurioje BVPG pagal palyginamosios galios standartus mažesnè negu 50 proc., palyginti su ES sukurtu BVPG lygiu, buvo dvi šalys: Bulgarija - 45 proc. ir Makedonija - 36 proc. Didžiausia BVPG pagal perkamosios galios standartus 2013 m. buvo: Liuksemburge - 257 proc., Norvegijoje - 188 proc., Šveicarijoje -163 proc., Nyderlanduose - 131 proc., Airijoje - 130 proc., Austrijoje - 128 proc. ir Švedijoje - 127 proc. ES sukurto BVPG lygio pagal perkamosios galios standartus vidurkị 2013 m. labiausiai atitiko Italija - 99 proc. ir Prancūzija - 107 proc. 


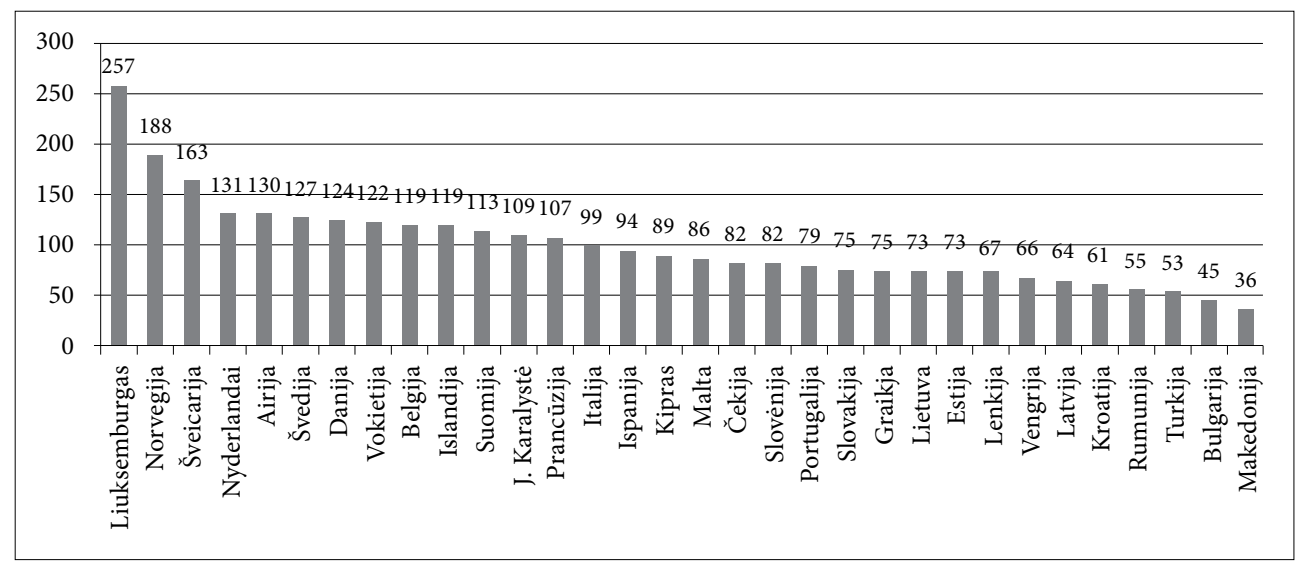

1 pav. BVPG Europos šalyse pagal perkamosios galios standartus palyginti su ES BVPG 2013 m., \%

Šaltinis: „Eurostat“

Statistinių duomenų analizė rodo, kad Lietuvoje svarbu stiprinti svarbiausių žinių elementų, vadinamojo žinių trikampio, kurị sudaro švietimas, moksliniai tyrimai ir inovacijos, sąveiką, padidinti veiklos rezultatą - šalies BVP ir BVPG. Šia kryptimi Lietuvoje nukreiptas aukštasis mokslas, nes jo tikslai yra (Lietuvos Respublikos mokslo ir studijų įstatymas, 2009):

1) studijų lygis turi asmeniui suteikti žinias, mokslinių tyrimų atlikimo igūdžius ir gebejimus jiems atlikti bei vadovauti. Studijos turi išugdyti visapusiškai išsilavinusią, pareigingą, kūrybingą ir verslią asmenybę, visapusiškai pasirengusią nuolat besikeičiančios darbo rinkos poreikiams;

2) darniai plètoti ịvairių sričių mokslinị pažinimą, vykdyti aukšto lygio MTEP, rengti mokslininkus ir bendradarbiauti mokslo srityje su šalies ir užsienio partneriais;

3) bendradarbiaujant su visuomenès ir ūkio partneriais, moksline, šviečiamaja, meno ir kita kultūrine veikla skatinti regionų ir visos šalies raidą;

4) ugdyti švietimui, mokslui, menui ir kultūrai imlią visuomenę, gebančią veiksmingai naudotis mokslu ir konkuruoti aukšto lygio technologijų, gaminių ir paslaugų rinkoje.

Žiniu trikampio elementų sąveika užtikrina bet kurios šalies ūkio veiklos rezultatų augimą, užimtumo didejjimą darbo rinkoje (ypač jaunimo užimtumo didèjimą) ir teigiamus konkurencingumo pokyčius įvairių sektorių rinkose (tiek vidaus, tiek užsienio). Tai prisidètų prie naujų verslų kūrimo ir sudarytų palankias sąlygas ekonomikai augti.

Aukštojo mokslo problemų tyrèjai, analizuodami aukštojo mokslo svarbą šiandieninès visuomenès raidai ir jo bruožus, atskleidžia ịvairius požiūrius (žr. 1 lent.). Autoriu pateikiamos įvairios aukštojo mokslo charakteristikos rodo, kad 
aukštasis mokslas yra siejamas su geresnių konkrečios studijų krypties dalykinių žinių, mokslinių tyrimų gebėjimų ugdymu; mokslo institucijų veiksmingumo bei bendradarbiavimo su suinteresuotomis šalimis, tiek verslo, tiek administracinėmis valstybės institucijų struktūromis, didinimu, siekiant užtikrinti šalies ekonomini augimą.

\section{1 lentelè. Aukštojo mokslo charakteristikos}

\begin{tabular}{|c|c|}
\hline Autoriai/šaltiniai & Aukštąji išsilavinimą charakterizuoja kaip \\
\hline $\begin{array}{l}\text { Melnikas, 2011; } \\
2014\end{array}$ & $\begin{array}{l}\text { - naujų žinių kūrimą, } \\
\text { - ekonominių veiklų modernizatorių, } \\
\text { - naujų darbo vietų kūrimo veiksnị, } \\
\text { - verslumą skatinantį faktorių. }\end{array}$ \\
\hline Permanini, 2009 & $\begin{array}{l}\text { - mechanizmą technologinių žinių kaupimui, } \\
\text { - efektyvumą ir produktyvumą didinantį veiksnị. }\end{array}$ \\
\hline $\begin{array}{l}\text { Jones, Vollrath, } \\
2013\end{array}$ & - technologinės pažangos akceleratorių. \\
\hline Kwack, Lee, 2012 & $\begin{array}{l}\text { - tiesioginị poveikị ekonominiam augimui, } \\
\text { - } \text { papildinị kitiems veiksniams, pvz., šalies ekonominiam atvirumui, } \\
\text { - netiesiogini poveikị ekonominiam augimui, kai išsimokslinimo } \\
\text { lygis šalyje didèja dėl kitų ekonominio vystymosi veiksnių diegimo, } \\
\text { pvz., tiesioginių užsienio investicijų (Narayan, Smyth, 2006). }\end{array}$ \\
\hline
\end{tabular}

$\mathrm{XX}$ a. antrojoje pusejje išryškejjusios europinès dimensijos ugdyme paskatino edukacinès paradigmos kaitą. Mokymo procesas, kuris buvo nukreiptas tik ị turinio išdèstymą, informacijos įsiminimą ir atkartojimą, nuolat kintančioje visuomenejje tapo nepakankamas, todèl prireikè naujo mokymo(-si) sampratos turinio. Naujasis šiandieninis mokymas (-is) remiasi savianalize, planavimu, refleksija, pagrịstas savo kompetencijos (-ų) tobulinimu, vykstantis bet kokioje žmogaus veikloje ir besitęsiantis visą gyvenimą. Ypatingas demesys atkreipiamas ị reflektyvią praktiką, kuri suprantama kaip mokymasis iš savo patirties, įgyjant aukštesnio lygio supratimą apie veiklos prigimtį ir poveikị.

Šiuolaikine ugdymosi paradigma. Šiuolaikiniame pasaulyje kiekvienas žmogus nuolat susiduria su vis naujomis ir greitai kintančiomis situacijomis, reikalaujančiomis ypač kompleksinių problemų sprendimo, o tam - vis naujų žinių ir gebejjimų.

Paradigma - esminis teorinis požiūris, kurio susitarta laikytis (Jucevičienè, Čiužas, 2006). Galima išskirti tris mokymo(-si) paradigmas: tradicinè (poveikio), sąveikos ir mokymosi. Visas jas galima analizuoti remiantis penkiais pagrindiniais kriterijais: darbo stiliaus, mokymo tikslų ir metodų, mokymo(-si) aplinkos ir ugdytojo bei mokinio sąveikos (Jucevičienè, Čiužas, 2006).

Ugdymas šiuolaikinèje aukštojoje mokykloje yra vienas iš būdų, kaip ma- 
kroekonominiu (atskira valstybė), mikroekonominiu (institucija, organizacija, pvz., aukštoji mokykla, arba individas, pvz., studentas, dėstytojas) lygiu gali būti reaguojama ị globalizacijos daromą įtaką žinių visuomenei. Skiriami ịvairūs veiksniai (tiesioginiai, netiesioginiai), kurie įvairiapusiškai veikia aukštojo mokslo kokybę (teigiamai, neigiamai ar neutraliai). Vienas iš svarbiausių veiksnių, teigiamai veikiančiu aukštojo mokslo kokybę, yra ịvairių kompetencijos lygių ugdymas ir europinių kompetencijų siekimas. Kompetencija - tai individo žinios, gebejjimai, igūdžiai, požiūriai, asmeninès savybės ir vertybès, lemiančios jo kvalifikacijos raišką arba gebejjimą veikti. Kompetencijų lygiai (žr. 2 lent.) skiriami pagal darbo atlikimo pobūdị: atitinkant minimalius standartus - redukuota / fragmentuota kompetencija ir keliant tikslą kuo geriau atlikti darbą - holistinè, visuminè kompetencija. Abiems kompetencijų lygiams būdinga tai, kad atkreipiamas dėmesys ị konkretų darbą, veiklos subjektą ir objektą, bet veiklos rezultatas akcentuojamas skirtingas.

\section{2 lentelè. Kompetencijų tipai pagal darbo atlikimo pobūdị}

\begin{tabular}{|l|l|}
\hline \multicolumn{1}{|c|}{$\begin{array}{c}\text { Redukuota / fragmentuota } \\
\text { kompetencija }\end{array}$} & \multicolumn{1}{c|}{ Holistinè / visuminė kompetencija } \\
\hline 1. Rezultatas pagal minimalius standartus & 1. Pastangos kuo geriau atlikti darbą \\
\hline 2. Rūpinimasis tik tuo, ko reikalauja darbas & 2. Rūpinimasis, kaip žmonės pasirengę darbui \\
\hline 3. Sociologinis požiūris & 3. Psichologinis požiūris \\
\hline $\begin{array}{l}\text { 4. Redukcionizmas - stebejimas ir } \\
\text { vertinimas konkrečioje darbo vietoje } \\
\text { pagal darbų atlikimo standartus }\end{array}$ & $\begin{array}{l}\text { 4. Holistika - visuminis naujos situacijos } \\
\text { vertinimas, darbuotojo sprendimai } \\
\text { neapibrèžtoje situacijoje }\end{array}$ \\
\hline
\end{tabular}

Šaltinis: sudaryta pagal Trotter, Ellison, 1997

XXI amžiuje ịvairios kompetencijos, reikalingos nūdienos darbo rinkoje, ugdomos mokantis visą gyvenimą. Visose ES šalyse siekiama ugdyti pagrindines europines kompetencijas, kurios kaip pagrindinès mokymosi visą gyvenimą procese buvo suformuluotos ir paskelbtos 2007 metais (Key Competences for..., 2007). Pagrindinès europinès kompetencijos ir jų charakteristikos pateiktos 3 lent.

3 lentelè. Pagrindinės europinès kompetencijos, ugdomos visą žmogaus gyvenimą

\begin{tabular}{|c|c|l|}
\hline $\begin{array}{c}\text { Eil. } \\
\text { nr. }\end{array}$ & $\begin{array}{c}\text { Pagrindinès } \\
\text { europinės } \\
\text { kompetencijos }\end{array}$ & Kompetencijos apibūdinimas / charakteristika \\
\hline 1 & $\begin{array}{c}\text { Gebėjimas laisvai } \\
\text { ir lengvai bendrauti } \\
\text { gimtaja kalba }\end{array}$ & $\begin{array}{l}\text { Bendravimas gimtaja kalba reiškia gebèjimą reikšti savo mintis ir jaus- } \\
\text { mus, pateikti faktus ir pagrịsti nuomonę žodžiu ir raštu (klausymas, kal- } \\
\text { bèjimas, skaitymas ir rašymas) ịvairioje socialineje ir kultūrinèje aplin- } \\
\text { koje: švietimo ir mokymo srityje, darbe, namuose ir laisvalaikiu. }\end{array}$ \\
\hline
\end{tabular}




\begin{tabular}{|c|c|c|}
\hline 2 & $\begin{array}{c}\text { Gebejjimas } \\
\text { bendrauti užsienio } \\
\text { kalbomis }\end{array}$ & $\begin{array}{l}\text { Bendravimas užsienio kalbomis didžiaja dalimi apima pagrindinius igū- } \\
\text { džius bendravimo gimtaja kalba ir yra pagrįstas gebejjimu suprasti, reikšti } \\
\text { savo mintis ir jausmus, pateikti faktus ir pagrịsti nuomonę žodžiu ir raštu } \\
\text { (klausymas, kalbėjimas, skaitymas ir rašymas) atitinkamoje visuomeni- } \\
\text { neje ir kultūrinėje aplinkoje (švietimo ir mokymo srityje, darbe, namuose } \\
\text { ir laisvalaikiu) pagal kiekvieno norus ir (ar) poreikius. Bendravimas } \\
\text { užsienio kalbomis reikalauja ir tarpkultūrinio supratimo igūdžių. Asmens } \\
\text { mokejjimo bendrauti užsienio kalba lygis priklauso nuo keturiu gebejjimų } \\
\text { (klausymo, kalbèjimo, skaitymo ir rašymo), nuo individo socialinio ir } \\
\text { kultūrinio išsilavinimo, aplinkos ir poreikių. }\end{array}$ \\
\hline 3 & $\begin{array}{l}\text { Matematiniai ir } \\
\text { pagrindiniai mokslo } \\
\text { ir technologijų } \\
\text { srities sugebéjimai }\end{array}$ & 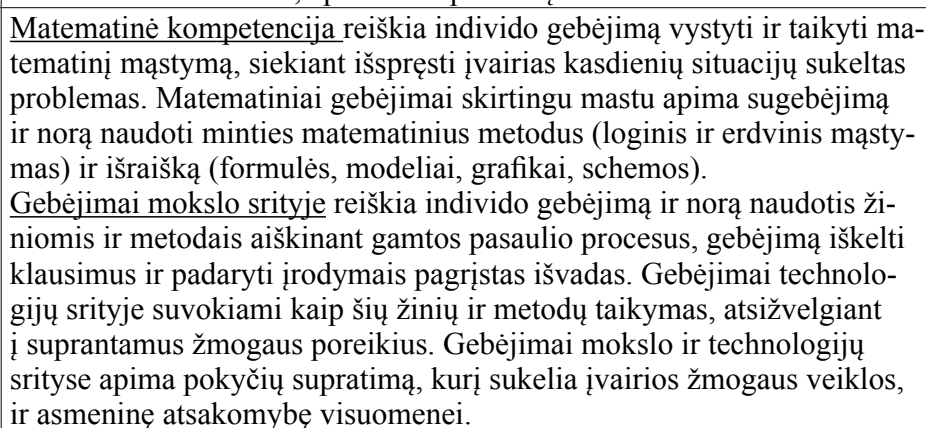 \\
\hline 4 & IT sugebèjimai & $\begin{array}{l}\text { Skaitmeninis raštingumas siejasi su patikimu ir kritišku informacinės vi- } \\
\text { suomenės technologijų naudojimu darbe, leidžiant laisvalaiki ir bendrau- } \\
\text { jant. Jis yra paremtas pagrindiniais IT igūdžiais: kompiuterių naudojimu } \\
\text { surandant, ivertinant, saugant, rengiant, pristatant informaciją ir ja kei- } \\
\text { čiantis bei bendraujant ir dalyvaujant socialiniuose tinkluose internete. }\end{array}$ \\
\hline 5 & $\begin{array}{l}\text { Mokymasis } \\
\text { mokytis }\end{array}$ & 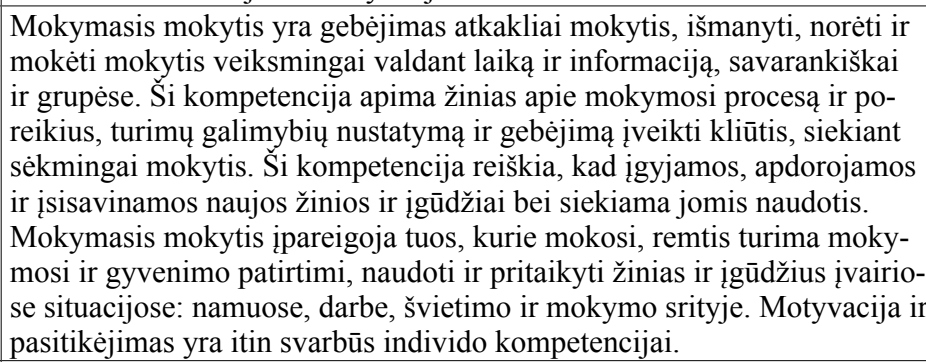 \\
\hline 6 & $\begin{array}{l}\text { Socialiniai ir } \\
\text { pilietiniai } \\
\text { gebejjimai }\end{array}$ & $\begin{array}{l}\text { Apima asmeninius, tarpasmeninius ir tarpkultūrinius gebejjimus ir aprè- } \\
\text { pia visas elgesio formas dalyvaujant veiksmingame ir konstruktyviame } \\
\text { socialiniame gyvenime ir darbo aplinkoje, reiškiant ir ginant visuome- } \\
\text { ninius poreikius ir sprendžiant konfliktus. Pilietinis gebejjimas padeda } \\
\text { žmonèms visapusiškai dalyvauti pilietiniame gyvenime remiantis žinio- } \\
\text { mis apie socialinius ir politinius procesus bei struktūras ir įsipareigoti } \\
\text { aktyviam ir demokratiškam dalyvavimui. }\end{array}$ \\
\hline 7 & $\begin{array}{l}\text { Iniciatyvumas ir } \\
\text { verslumas }\end{array}$ & $\begin{array}{l}\text { Iniciatyvumas ir verslumas reiškia žmogaus gebejimą idèjas paversti } \\
\text { veiksmais. Jis reiškia kūrybiškumą, naujoves ir pasirengimą rizikuoti, o } \\
\text { taip pat gebejjimą planuoti ir valdyti projektus, siekiant iškeltu tikslų. Tai } \\
\text { naudinga kiekvienam žmogui ne tik kasdieniame gyvenime, bet taip pat } \\
\text { ir darbinejje veikloje. Tai apima supratimą apie etines vertybes ir skatina } \\
\text { gerą veiklos organizavimą. }\end{array}$ \\
\hline 8 & $\begin{array}{l}\text { Kultūrinis sąmonin- } \\
\text { gumas ir raiška }\end{array}$ & $\begin{array}{l}\text { Ivairiu kūrybinių idèjų, patirties ir emocijų raiška skirtingose terpèse, } \\
\text { įskaitant muziką, scenos meną, literatūrą ir vaizduojamaji meną. }\end{array}$ \\
\hline
\end{tabular}

Šaltinis: sudaryta pagal Key Competences for Lifelong Learning..., 2007; European Reference Framework. Luxembourg..., 2007. 
Naujasis šiandieninis mokymas(-is) aukštosiose mokyklose greta ịprastų kompetencijų (profesinès, socialinès, bendrakultūrès, komunikacinès) reikalauja ugdyti ir naujas kompetencijas (pvz., efektyvios veiklos, informacijos valdymo ir pokyčių valdymo), kurios padètu jaunimui lengviau integruotis ị darbo rinką (žr. 4 lent.).

\section{4 lentelè. Aukštojoje mokykloje ugdomos kompetencijos}

\begin{tabular}{|c|c|}
\hline Kompetencija & Trumpa charakteristika \\
\hline $\begin{array}{c}\text { Profesiné } \\
\text { kompetencija }\end{array}$ & $\begin{array}{l}\text { - asmens igytos teorinès žinios ir praktiniai igūdžiai, kurie atitinka } \\
\text { igytos ir (ar) diplome ar licencijoje nurodytos specialybės reikala- } \\
\text { vimus. Aukštujų mokyklų absolventų kompetencija atitiktų visuo- } \\
\text { menès ir darbo rinkos poreikius pagal išsilavinimą ir kvalifikacijų } \\
\text { struktūrą šiuo metu ir ateityje. }\end{array}$ \\
\hline $\begin{array}{c}\text { Socialiné } \\
\text { kompetencija }\end{array}$ & $\begin{array}{l}\text { - pasireiškia gebejjimu bendrauti su savo darbo kolegomis ir adminis- } \\
\text { tracijos darbuotojais, meistriškumu ir socialinės elgsenos igūdžiais, } \\
\text { lemiančiais asmenybès elgesị konfliktinėse situacijose, darbo orga- } \\
\text { nizavimo, pareigų ir atsakomybės už produktą suvokimu; ji padeda } \\
\text { pažinti save, savo socialinius poreikius ir vaidmenis organizacijoje / } \\
\text { bendruomenèje, tolerancija skirtingai kolegų, mokinių, bendruome- } \\
\text { nės narių ịvairovei. Socialinei kompetencijai priskiriami žmogaus } \\
\text { gebėjimai susirasti sau darbą ir tinkamai ,pristatyti save“ darbdaviui } \\
\text { ieškant darbo, taip pat socialiniai pilietiniai gebejjimai. }\end{array}$ \\
\hline $\begin{array}{l}\text { Bendrakultūrè } \\
\text { kompetencija }\end{array}$ & $\begin{array}{l}\text { - žinios, gebèjimai, požiūriai, vertybės ir kitos asmeninės savybės, } \\
\text { sąlygojančios sėkmingą žmogaus veikimą konkrečioje (-ose) kultū- } \\
\text { roje (-ose). }\end{array}$ \\
\hline $\begin{array}{l}\text { Efektyvios veiklos } \\
\text { kompetencija }\end{array}$ & $\begin{array}{l}\text { - žinios, gebèjimai, požiūriai, vertybės ir kitos asmeninės savybės, } \\
\text { igalinančios pasiekti rezultatą, nenukrypstant nuo užsibrėžto tikslo. }\end{array}$ \\
\hline $\begin{array}{c}\text { Komunikacine } \\
\text { kompetencija }\end{array}$ & $\begin{array}{l}\text { - žinios, gebėjimai, požiūriai, vertybės ir kitos asmeninės savybės, } \\
\text { sąlygojančios informacijos, susijusios su žmonių tarpusavio ryšiais, } \\
\text { sėkmingą konstravimą, perdavimą, prièmimą ir interpretavimą. }\end{array}$ \\
\hline $\begin{array}{l}\text { Informacijos } \\
\quad \text { valdymo } \\
\text { kompetencija }\end{array}$ & $\begin{array}{l}\text { - žinios, gebėjimai, požiūriai ir vertybės bei kitos asmeninės savybės, } \\
\text { sąlygojančios sėkmingą ịvairios formos informacijos paiešką, kaupi- } \\
\text { mą, apdorojimą ir sklaidą. }\end{array}$ \\
\hline $\begin{array}{l}\text { Pokyčiu valdymo } \\
\text { kompetencija }\end{array}$ & $\begin{array}{l}\text { - žinios, gebejjimai, požiūriai ir vertybès bei kitos asmeninès savybès, } \\
\text { igalinančios ičzelgti, sėkmingai diegti bei vertinti planuotus ir nepla- } \\
\text { nuotus pokyčius. }\end{array}$ \\
\hline
\end{tabular}

Šaltiniai: sudaryta pagal Jucevičienè, Lepaitè, 2000, 2002;

Lepaitè, 2003; Adamonienè, Ruibytè, 2010 


\section{Žinių trikampis: MTEP ir inovacijos}

Nuo ugdymo derinimo šiuolaikineje aukštojoje mokykloje, t. y. nuo ugdymo paradigmų ir jų poveikio šiandieninių specialistų kompetencijų ugdymui, priklauso šalies žinių trikampio realizavimas šalies inovacijų lygmeniu. Kompetencijų rezultatai susiję su šalies ekonominès sistemos raida. Kiekvienos valstybès ekonominès sistemos veiklos rezultatai labai priklauso nuo MTEP ir pasireiškia inovacijomis ir jų plètra.

Lietuvos inovacijų plètros 2014-2020 metų programa parengta atsižvelgiant ị Lietuvos pažangos strategiją „Lietuva 2030“, patvirtintą Lietuvos Respublikos Seimo 2012 m. Inovacijų plètros strateginis tikslas - didinti Lietuvos ūkio konkurencingumą, kuriant efektyvią inovacijų sistemą, skatinančią ūkio inovatyvumą. Ši strategini tikslą galima realizuoti veikiant šiomis pagrindinèmis kryptimis (Lietuvos inovacijų plètros 2014-2020 m. programa, 2013):

- plètoti naujas žinias ir jų taikymą, ugdant inovatyvią visuomenę;

- didinti verslo inovacini potencialą;

- skatinti vertès tinklų kūrimą, plètrą ir jų tarptautiškumą;

- didinti inovacijų politikos formavimo ir įgyvendinimo efektyvumą ir skatinti inovacijas viešajame sektoriuje.

Visi ị strateginio tikslo ịgyvendinimą orientuoti uždaviniai susiję su skirtingomis veiklos sritimis, skatinančiomis inovacijų plètrą, i kurią orientuotos ne tik ES šalys, bet ir daugelis pasaulio valstybių. Būtent tai ir lèmé, kad nuo $2007 \mathrm{~m}$. Pasaulio intelektinès nuosavybès organizacija (PINO) kasmet sudaro inovacijų indeksą. Iš viso reitinguojama daugiau kaip140 pasaulio valstybių pagal maždaug 80 rodiklių, skiriant nuo 0 iki 100 balų. Šis indeksas reikšmingas visiems, kurie domisi inovacijų būklès pokyčiais pasaulyje, ar atskiroms valstybėms, verslo administratoriams, ekonominès politikos formuotojams, rizikos kapitalo bendrovėms ir kitiems, siekiantiems išsiaiškinti inovacijų būklę pasaulyje. $2015 \mathrm{~m}$. šalių inovacijų lyderių dešimtukas, kaip pavaizduota 2 pav.: pirma vieta - Šveicarija (68,3 balo), antra vieta - Jungtinè Karalystė $(62,42$ balo), trečia vieta - Švedija ( 62,4 balo), ketvirta vieta - Nyderlandai ( 61,58 balo) ir t. t. Iš Baltijos valstybių aukščiausią vietą užèmė Estija - 23 vietą ( 52,81 balo), Latvija užèmè 33 vietą (45,51 balo) ir Lietuva buvo 38 vietoje (42,62 balo). 


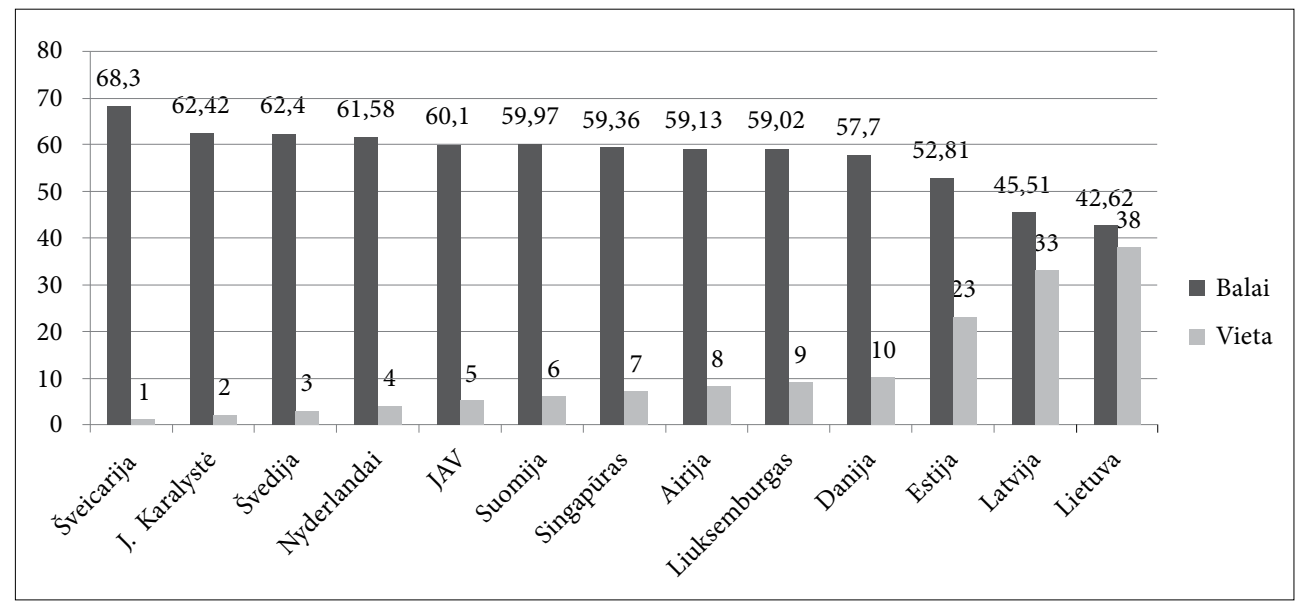

2 pav. Pasaulinis inovacijų indeksas: dešimties lyderių ir Baltijos šalių inovacijų indeksai ir užimtos vietos 2015 m.

Baltijos šalių padètis pagal užimamą vietą pasauliniame inovacijų indekse 2012-2015 m., kaip rodo 5 lentelès duomenys, kito. Baltijos šalyse 2013 m., palyginti su 2012 m., pasaulinis inovacijų indeksas šiek tiek sumenko ir užimama padètis pablogèjo:

- Lietuva nukrito per 2 vietas (iš 38 vietos i 40 vietą),

- Estija - per 6 (iš19 vietos į 25 vietą),

- Latvija - per 3 (iš 30 vietos ị 33 vietą).

Baltijos šalių pasiekti pasaulinio inovacijų indekso rezultatai $2015 \mathrm{~m}$., palyginti su 2013 m., rodo, kad situacija pagerejo Lietuvoje ir Estijoje:

- Lietuva pagerino savo užimamą padèti per dvi vietas ir sugrịžo į $2012 \mathrm{~m}$. lygi (iš 40 vietos ị 38 vietą),

- Estija - per 2 (iš 25 vietos ị 23 vietą), bet nepasiekè 2012 m. užimtos 19 vietos;

- Latvija - liko toje pačioje 33 vietoje, užimtoje 2013 m., bet nepasiekè $2012 \mathrm{~m}$. užimtos 30 vietos.

Lietuva tarp Baltijos valstybių 2012-2015 m. pasižymėjo mažiausiu inovatyvumo lygiu.

5 lentelè. Baltijos šalių pasaulinio inovacijų indekso pagal užimamą vietą kitimas 2012-2015 m.

\begin{tabular}{|c|c|c|c|}
\hline Šalys / metai & 2012, vieta & 2013, vieta & 2015, vieta \\
\hline Lietuva & 38 & 40 & 38 \\
\hline Estija & 19 & 25 & 23 \\
\hline Latvija & 30 & 33 & 33 \\
\hline
\end{tabular}

Šaltinis: Pasaulinė intelektinès nuosavybės organizacija (PINO), 2015 
Šalies užimta žemesnè vieta pasauliniame inovacijų indekse dar nebūtinai reiškia bendrų rezultatų pablogejjimą. Nuolat besikeičiančiame pasaulyje kinta ir dalis inovacijų kriterijų. Atskirai šaliai naujieji kriterijai gali būti mažiau palankūs, todèl svarbesnè ne tiek konkreti užimama vieta, bet lyginamoji atskirų indekso aspektų analizè. Pasauliniame inovacijų indekse žinių trikampio elementai (švietimas, moksliniai tyrimai ir inovacijos) atsispindi skyriuje „Žmogiškieji ištekliai ir moksliniai tyrimai“. Svarbiausi šio skyriaus rodikliai ir jų rezultatų kitimas 2012-2015 m. pateiktas 6 lentelèje.

6 lentelè. Pasaulinio inovacijų indekso skyriaus „Žmogiškieji ištekliai ir moksliniai tyrimai“" struktūrinių elementų vietos kitimas Lietuvoje 2012-2015 m.

\begin{tabular}{|c|c|c|c|c|c|}
\hline Rodiklis & 2012 & 2013 & 2014 & 2015 & $\begin{array}{c}\text { Vietos } \\
\text { kitimas } \\
\text { 2012-2015 m. }\end{array}$ \\
\hline $\begin{array}{c}\text { Vieta pagal skyriụ „Žmogiškieji ištekliai } \\
\text { ir moksliniai tyrimai““ }\end{array}$ & 37 & 35 & 34 & 41 & -4 \\
\hline 2.1. Švietimas & 37 & 35 & 32 & 40 & -3 \\
\hline $\begin{array}{l}\text { 2.1.1. Einamosios išlaidos švietimui, \% nuo } \\
\text { BNP }\end{array}$ & 59 & 34 & 46 & 48 & 11 \\
\hline $\begin{array}{l}\text { 2.1.2. Viešosios išlaidos /mokiniui, \% nuo } \\
\text { BVPG }\end{array}$ & 58 & 37 & 48 & 60 & -2 \\
\hline 2.1.3. Tikètina mokymosi trukmè, metais & 20 & 29 & 12 & $17+$ & 3 \\
\hline $\begin{array}{l}\text { 2.1.4. PISA skalé: skaitymas, matematika, gam- } \\
\text { tos mokslai }\end{array}$ & 34 & 34 & 32 & 32 & 2 \\
\hline $\begin{array}{l}\text { 2.1.5. Mokiniu ir mokytojų skaičiaus santykis } \\
\text { (vidurinis ugdymas) }\end{array}$ & 17 & $13+$ & 10 & $10+$ & 7 \\
\hline 2.2. $\mathrm{AM}^{*}$ & 42 & 45 & 44 & 47 & -5 \\
\hline 2.2.1. Prièmimas ị AM*, \% & 10 & $20+$ & 13 & $20+$ & -10 \\
\hline $\begin{array}{l}\text { 2.2.2. } \text { AM }^{*} \text { gamtos mokslų ir inžinerijos } \\
\text { absolventai, } \%\end{array}$ & 48 & 37 & 43 & 36 & 12 \\
\hline 2.2.3. Atvykstamosios AM* studijos, \% & 70 & 66 & 69 & 70 & 0 \\
\hline 2.2.4. Išvykstamosios $\mathrm{AM}^{*}$ studijos, $\%$ & 29 & 29 & 33 & $\mathrm{n}$ & \\
\hline 2.3. MTEP & 35 & 39 & 19 & 37 & -2 \\
\hline 2.3.1. Tyrëjų, $/ \mathrm{mln}$. gyventojų & 25 & 23 & 36 & 29 & -4 \\
\hline 2.3.2. Bendrosios MTEP išlaidos, $\%$ nuo BVP & 39 & 39 & 54 & 36 & 3 \\
\hline 2.3.3. Mokslinių tyrimų institucijų kokybè** & 35 & 52 & 34 & 53 & -18 \\
\hline
\end{tabular}

*AM - aukštasis mokslas; ** - sudètinis rodiklis

Šaltiniai: Lietuvos mokslas skaičiais 2015, p. 33; Lietuvos mokslas skaičiais 2014, p. 34; Lietuvos mokslas skaičiais 2013, p. 35; Lietuvos mokslas skaičiais 2012, p. 35 
Bendra Lietuvos vieta (žr. 6 lent.) pagal „Žmogiškujų išteklių ir mokslinių tyrimų" skyrių smuko per 4 pozicijas: nuo 37 vietos $2012 \mathrm{~m}$. iki 41 vietos $2015 \mathrm{~m}$., nes sumenko tiek švietimo (-3), tiek aukštojo mokslo (-5) užimamos vietos rodiklio struktūroje. Pažymètina, kad atskirų struktūrinių elementų rezultatai pagerejo, pavyzdžiui, ị aukštesnes vietas pakilo pagal einamąsias išlaidas švietimui, tikètiną mokymosi trukmę, aukštojo mokslo gamtos mokslų ir inžinerijos absolventų skaičių ir tyrèjų skaičių. Kadangi rodiklių svarba indekse skirtinga, tai vienų rodiklių sumažèjimo nekompensuoja kitų rodiklių padidèjimas. Duomenys rodo, kad Lietuvoje yra prielaidos inovacijoms, tačiau kol kas nepasiekti rezultatai: menka dalis prekių ir paslaugų gaminama ir eksportuojama naudojantis aukštosiomis technologijomis. Todèl žmogiškųjų išteklių kūrybiškumui, kaip vienam svarbiausių inovacijų požymių, plètoti itin reikšminga tinkama aukštojo mokslo politika ir jo sąveika su verslu, ugdanti kompetencijas.

\section{Išvados}

- ES šalys akcentuoja pagrindinių europinių kompetencijų ugdymą. Pastebima, kad kompetencijų ugdymo sèkmè priklauso nuo mokymo(-si) paradigmų, taikomų mokymo procese. Daugeliu atvejų sèkmingiausias šiandieninis mokymas(-is), skatinantis tuos, kurie mokosi, remtis savianalize, planavimu, atsakomybe už savo mokymąsi, orientacija ị individualumą ir grupinị sprendimų prièmimą, kūrybinị darbą su informacijos šaltiniais ir kt.

- Siekiant spręsti Lietuvos aukštojo mokslo problemas būtina sustiprinti mokslo ir verslo ryšius / kooperaciją. Kita vertus, pažangus vystymasis turi būti grindžiamas žinių trikampio elementais, kurị sudaro švietimas, moksliniai tyrimai ir inovacijos.

- Pasaulinis inovacijų indeksas skaičiuojamas nuo 2007 metų. Šiame procese dalyvauja 140-142 šalys, kurios yra vertinamos daugiau nei pagal 80 kriterijų. Pagrindinių europinių kompetencijų ugdymas daro įtaką pasaulinio inovacijų indekso rodikliams. Ypač atkreiptinas dèmesys $\mathfrak{i}$ grupę rodiklių, pateikiamų skyriuje „Žmogiškieji ištekliai ir moksliniai tyrimai“ (švietimas, aukštasis mokslas ir MTEP). Palyginamoji analizė rodo, kad Lietuva pagal užimamą vietą pasauliniame inovacijų indekse labai atsilieka nuo Estijos ir kiek mažiau nuo Latvijos, todèl itin svarbu ugdyti europines kompetencijas ir siekti holistinių kompetencijų lygio. 


\section{Literatūra}

1. Adamonienè, R.; Ruibyte, L. (2010). Vadovų kompetencijų ugdymo sistemos formavimo kryptys.//Vadybos mokslas ir studijos - kaimo verslų ir jų infrastruktūros plètrai// Mokslo darbai, 5 (24), 20. Kaunas: LŽŪU, p. 6-14.

2. Europos aukštojo mokslo sistemų modernizavimo darbotvarkè. Ekonomikos rèmimo ir užimtumo rẻmimas. Briuselis. (2011). p. 3. [žiūrèta 201510 28]. Prieiga per internetą: http://ec.europa.eu/education/pub/pdf/higher/modernisation lt.pdf).

3. Europe 2020. A European Strategy for Smart, Sustainable and Inclusive Growth. [žiūrèta 201511 27]. Prieiga per internetą: http://ec.europa.eu/eu2020/ pdf/COMPLET\%20EN\%20BARROSO \%20\%20\%20007\%20-\%20Europe \%20 2020\%20-\%20EN\%20version.pdf.

4. European Reference Framework. Luxembourg, Office for Official Publications of the European Communities. (2007). [žiūreta 201509 18]. Prieiga per internetą: https://www.britishcouncil.org/sites/default/files/youth-in-actionkeycomp-en.pdf.

5. „Eurostat“ duomenys. [žiūrèta 201601 10]. Prieiga per internetą: http:// ec.europa.eu/eurostat $/ \mathrm{tgm} / \mathrm{table} . \mathrm{do} ? \mathrm{tab}=$ table $\&$ init $=1 \&$ plugin $=1 \&$ pcode $=$ tec 00114 \&language $=\mathrm{en}$.

6. Industrial Relations in Europe 2010. (2010). European Commission, 2010.

7. Jucevičienè, P.; Čiužas, R. (2006). Lietuvos mokytojų didaktinè kompetencija// Švietimo problemos analizè, Nr. 5(8).

8. Jucevičienè, P.; Lepaitè, D. (2000). Kompetencijos sampratos erdvè// Socialiniai mokslai. Nr. 1 (22), p. 44-50.

9. Jucevičienè, P.; Lepaite, D. (2002). Evaluator as Feed-Back Driver: European Competences and Contemporary Training Problems. Socialiniai mokslai. Nr. 4 (36). P. 57-63.

10. Key Competences for Lifelong Learning. European Reference Framework. Education and Training. Belgium. (2007). [žiūrèta 201508 20]. Prieiga per internetą: https://www.britishcouncil.org/sites/default/files/youth-in-actionkeycomp-en.pdf.

11. Kwack, S. Y; Lee, Y. S. (2012). Analyzing the Korea's Growth Experience: the Application of R\&D and Human Capital Based Growth Models with Demography. Journal of Asian Economics, 17(5) 818-831.

12. Lepaité, D. (2003). Kompetenciją plètojančių studijų programų lygio nustatymo metodologija. Kaunas: Technologija.

13. Lietuvos inovacijų plètros 2014-2020 m. programa. (2013). LR Vyriausybè.

14. Lietuvos mokslas skaičiais 2012. (2012). Vilnius: MOSTA.

15. Lietuvos mokslas skaičiais 2013. (2013). Vilnius: MOSTA.

16. Lietuvos mokslas skaičiais 2014. (2014). Vilnius: MOSTA. 
17. Lietuvos mokslas skaičiais 2015. (2015). Vilnius: MOSTA.

18. Lietuvos Respublikos mokslo ir studijų ịstatymas, Žin. (2009) Nr. 54-2140, Nr. 61, Nr. 101, 2009 m. balandžio 30 d. Nr. XI-242, Vilnius.

19. Lietuvos pažangos strategija „Lietuva 2030“. (2012). [žiūrèta 20151028 ]. Prieiga per internetą: http://www3.lrs.lt/pls/inter3/dokpaieska.showdoc_1?p_ $\mathrm{id}=425517 \& \mathrm{p} \_q u e r y=\& \mathrm{p} \_\mathrm{tr} 2=2$.

20. Melnikas, B. (2014). Tarptautinis verslas: inovacijos ir žinių ekonomikos kūrimas. Vadovèlis. Vilnius: VGTU leidykla „Technika“.

21. Melnikas, B. (2011). Transformacijų visuomenè: ekonomika, kultūra, inovacijos, internacionalizacija. Vilnius: Vilniaus universitetas.

22. Narayan, P. K., Smyth. R. (2006). Higher Education, Real Income and Real Investment in China: Evidence from Granger Causality Tests. Education Economics, 14(1), 107-125.

23. New Priorities for European Cooperations: New Priorities. European Commission. (2015). [žiūrèta 201511 10]. Prieiga per internetą: http://ec.europa. eu/education/news/2015/0901-et2020-new-priorities_en.htm.

24. Rethinking Education: Investing in Skills for Better Socio-economic Outcomes. European Commission. (2012). p. 3.

25. Jones, C. I.; Vollrath, D. (2013). Introduction to Economic Growth (3th ed.). New York: W. W. Norton \& Company, Inc.

26. Mingat, A.; Tan, J. (1996). The Full Social Returns to Education: Estimates Based on Countries' Economic Growth Performance. World Bank, Washington, DC, 1-30.

27. Permanini, R. (2009). The Role of Education in Economic Growth in East Asia: a Survey. Asian Pacific Economic Literature, 1-20.

28. Trotter, A.; Ellison, L. (1997). Understanding Competence and Competency. In B. Daviesand L. Ellison (Eds.), School Leadership for the 21st Century, pp. 36-53, London: Routledge Falmer.

29. Pasaulinė intelektinès nuosavybès organizacija (PINO). [žiūrèta 201510 28]. Prieiga per internetą: https://www.urm.lt/default/lt/uzsienio-politika/ tarptautines-sutartys/konvencijos/pasaulines-intelektines-nuosavybes-organizacija. 


\title{
HARMONY OF EDUCATION IN A HIGHER SCHOOL
}

\author{
Assoc. Prof. Dr. Jūratė Guščinskienė \\ The General Jonas Žemaitis Military Academy of Lithuania \\ Prof. Dr. Jadvyga Čiburienè \\ Kaunas University of Technology
}

\section{Summary}

The experience of advanced countries indicates that knowledge-based economy, the industry of high technologies, the development of scientific research and experiments (SR\&ED) create better added value and improve economic and social state of consumers. Skills, knowledge, qualifications and competences become more and more important factors to improve well-being of a society; they are a prerequisite for advanced, sustainable and integrated economic development strategy.

The scientific problem of the article is the interaction and harmony of higher education studies, scientific research and innovation. The subject-matter of the research is education in a higher school. The goal of the research is to analyse the harmony of education in a contemporary higher school: education paradigm and its effect on the development of specialist competences in a knowledge society and their influence on the Global Innovation Index.

Having analysed the scientific problem and literature, having compared scientific data, having applied the analysis of tables and graphs, it was stated that 1) EU countries emphasise the education of the main European competencies. It is noticeable that the success of competence education depends on learning/teaching paradigms applied in the education process. In the majority of cases successful contemporary learning/teaching encourages students to apply self-analysis, planning and responsibility for their own learning and orientates towards individuality, group decision-making and creative work with information sources, etc.; 2) it is necessary to strengthen the relations and cooperation between education and industry, to solve the problem in Lithuanian higher education as an economic development factor. On the other hand, advanced development has to be based on the elements of knowledge triangle consisting of education, scientific research and innovation; 3) the education of the main European competences influences the Global Innovation Index. Special attention is to be paid to a number of indicators in the chapter "Human Resources and Scientific Research" (education, higher education and SR\&ED). A comparative analysis indicated that the Global Innovation Index ranked Lithuania significantly lower than Estonia and lower than Latvia. 


\section{AUTORIŲ LYDRAŠTIS}

Autoriaus vardas, pavardè: Jūratė Guščinskienè

Mokslo laipsnis ir vardas: Socialinių mokslų daktarè, docentė

Darbo vieta ir pareigos: Generolo Jono Žemaičio Lietuvos karo akademijos Universitetinių studijų instituto direktoré, Vadybos katedros docentè

Autoriaus mokslinių interesų sritys: organizacijų sociologija, socialinè deviacija, organizacijų komunikacija, aukštojo mokslo problemos ir kt.

Telefonas ir el. pašto adresas: (8 5) 210 3592, jurate.guscinskiene@mil.lt

Autoriaus vardas, pavardè: Jadvyga Čiburienè

Mokslo laipsnis ir vardas: socialinių mokslų daktaré, profesorė

Darbo vieta ir pareigos: Kauno technologijos universiteto Ekonomikos ir vadybos fakulteto Ekonomikos katedros profesore

Autoriaus mokslinių interesų sritys: makroekonomika, ekonominis augimas, ekonominè politika, ekonomikos stabilizavimo politika, jaunimo problemos ir kt.

Telefonas ir el. pašto adresas: (37) 3005 76, jadvyga.ciburiene@ktu.lt

\section{AUTHORS' COVER LETTERS}

Author's name and surname: Jūratė Guščinskienè

Academic degree and name: Doctor of Social Sciences, Associate Professor

Workplace and position: The General Jonas Žemaitis Military Academy of Lithuania, Institute of University Studies, Director

Author's research interests: sociology of organizations, organizational communication, social deviance, problems of higher education, etc.

Telephone and e-mail address: +370 5210 3592; jurate.guscinskiene@mil.lt

Author's name and surname: Jadvyga Čiburienè

Academic degree and name: Doctor of Social Sciences, Professor

Workplace and position: Kaunas University of Technology, School of Economics and Management, Department of Economics, Professor

Author's research interests: economic stabilization policy, macroeconomics, economic growth, economic policy, problems of higher education, etc.

Telephone and e-mail address: (37) 3005 76, jadvyga.ciburiene@ktu.lt 